\title{
Johan Heising's Cultural Concept and Its Influence on the Modern Study of the «Musical Middle Ages»
}

\author{
Olga Zhuravleva ${ }^{1, *}$, Natalia Alekseenko ${ }^{1}$, Natalya Garipova ${ }^{1}$, Olena \\ Veselova $^{1,2}$ \\ ${ }^{1}$ V.I. Vernadsky Crimean Federal University, Simferopol, Russia
${ }^{2}$ Honored artist of the Republic of Crimea
${ }^{*}$ Corresponding author. Email: olga.zhuravleva.1949@mail.ru
}

\section{ABSTRACT}

The article considers the cultural concept of the middle ages. J. Huizinga and its influence on modern music medieval studies. The main attention is paid to the problem of the nature of creative consciousness, the selfvalue of the culture of «joy, love, the «juicy maturity» of a full «human life», reflected in the types and forms of medieval art, which in many ways prepared the Renaissance of Northern Europe.

Keywords: "Autumn Of The Middle Ages», "Homo Ludens», "Diagnosis of a spiritual illness of our era», culturology, cultural philosophy, art of the middle ages, mythogem, mystery, mass, motet

\section{INTRODUCTION}

The cultural process of the turn of the XX-first decades of the XXI century is associated with the breaking of ideological stereotypes, a significant change in the worldview and philosophical and methodological attitudes of many Humanities in higher institutions of music education in various fields, including - «History of art», «History of art and musical styles», «History of musical culture», «History of foreign music», etc. The necessary and unswerving observance of the laws of dialectical and historical materialism, the theory of class determination of social development, and the atheistic worldview of the recent past of the USSR created an ideologically «biased» type of approach to substantiating the phenomena of musical culture and art of various historical epochs, slowing down the process of understanding many modern philosophical and cultural concepts for a long time. «In the current conditions, ideological compromise, and moreover, pluralism of views and assessments were impossible and excluded in the consideration of the most important issues of musical and historical courses. The stereotype of thinking in the conditions of formed principles, the lack of translations of scientific works of leading modern foreign historians, philosophers and culturologists, for a long time slowed down the development of higher music education» [1]. However, the introduction in 1980-90 of alternative philosophical and humanitarian disciplines (sociology, philosophy, cultural studies, sociology of religious studies, etc.) forced a significant change in the content and methodological approaches of musical and historical courses. Naturally, it is impossible to cover the entire range of recent problems, but it is possible and even necessary to note some of the most important concepts that significantly change the views on the overall assessment of the spiritual culture of the past. In this case, we will focus on the works of the Dutch historian, philosopher, and cultural critic J. Heisinger: «About the historical ideals of life» [2], «Duch civilisation in the seventeenth century and other essays» [3], «Homo Ludens. Essay. A Thinking Man. Ideas that can change the world» [4], among which a special place is occupied «Autumn of the Middle Ages. A study of the forms of life and thought in the fourteenth and fifteenth centuries in France and the Netherlands» [5], created by him at the first half of the XX century, but have retained their relevance in the present time.

\section{MATERIALS AND METHODS}

Works of the Dutch scientist, world- famous historian J. Heisings (1872-1945) came to Russia with a long delay, but immediately received recognition among specialists in various fields of knowledge. In 1988, the fundamental research «Autumn of the middle Ages» was published in Russian translation, and in 1992 "Homo Ludens» The Man who Plays») and «In the shadow of tomorrow» were published. This is only part of the theoretical legacy published in Europe in 9 volumes.

The basis of the popularity of the personality of Johan Helsinga and his research was prepared in the 1960-80-s by domestic researchers - S. Averintsev, S. Botkin, A. Mikhailov, N. kolodka, I. Rozovskaya, G. Tavrizyan. Their works for the first time present the original concept of the Dutch cultural scientist, his views on the history of world culture as a whole, its individual periods, including the middle ages.. At the same time, his humanistic ideas came to the USSR and were accepted thanks to the 
translations of novels by Thomas Mann, Hermann Hesse, as well as the first published studies of famous representatives of the "cultural philosophy» of the late XIX-first half of the XX century - K. Jaspers, M. Heidegger, Jose Ortega-y-Gasset.

Despite the fact that in his writings on the history of world culture Huizinga delves into the past, there is always a feeling present His works «On the spiritual disease of our age»(1935) and «Tortured peace» (1945) reflect the thinking about the fate of culture, relationship between culture and power, the crisis of spirituality in the forms of daily life, attitudes and values, facing a new reality this time. In the 30 s of the last century, the work «Homo Ludens» (1938) became very popular, which is characterized by a new approach in highlighting the essence, origin and evolution of culture. It is distinguished by the brightness and uniqueness of the idea, the author's encyclopedic erudition and the brilliance of the literary style. The cultural concept of the nature of art as «Ludens of consciousness and intellect», «Aesthetic pleasure» has become a turning point in modern cultural studies and art criticism

\section{DISCUSSION}

«Autumn of the middle Ages» (1919) became the most famous book of the historian. It was thanks to her that most of her contemporaries found out who J. Heisinga was, and were able to get acquainted with new trends in science

Huizinga has disputed the interpretation of many researchers. There are many contradictory points of view on the historical development of the European middle Ages. J. Huizinga offers a vision of the given era. It is important for him to understand how people lived in those remote times, what they thought, what they aspired to, what they considered valuable. In the subtitle «Autumn of the middle Ages», he formulates a very important idea - « the work is devoted to the study of life forms and forms of thought in the XIV and XV centuries in France and the Netherlands» [5]. He is interested in the «living past» of the formation and development of European society, where at the last stage (XIV-XV centuries) of medieval culture (its maturity), new sprouts of the gradually gaining strength of the Renaissance are formed. Referring to a time that is five centuries younger than our own. Continuing this thought, in his study of Ducal civilization, he later write: «We want to know how those new ideas and forms of life were born and flourished, the radiance of which will later reach its full bloom» [3].

The author's main attention is focused «...on the desire to convey the psychological atmosphere of medieval culture, to create an image of the era of chivalrous love and luxury, great virtues and vile vices, hopes and utopias, piety and cruelty" [5]. Further, J. Huizinga emphasizes: "The Life was so stormy and contrasting that it spread a mixed smell of «blood and Roses». The people of this era are giants with the heads of children, tossing between fear and naive joys, between cruelty and tenderness [5]. "Autumn of the middle Ages» is full of historical facts, events, names, geographical names that make history sound and real. Of course, in the chivalrous ideal there was much that was far from reality, replete with examples of cruelty, arrogance, treachery, greed. But it was an aesthetic ideal, made up of lofty feelings and colorful fantasies, freed from its sinful origins. "It is the chivalrous ideal captured in Chronicles, novels, poetry and biographies that gives J. Huizinga a place of honor in his research»- writes A. Lisovichenko [6].

The cultural concept of J. Helsinki very quickly entered the domestic one. medieval studies. This is confirmed by conferences, symposiums, scientific meetings of various levels, which were initiated by the Institute for humanitarian historical and theoretical research A.V. Poletaevaю The theme of the round table: «Unofficial Soviet middle ages and the cultural revolution» (February 10, 2015, Moscow) determined the direction of the problem itself. Publications of the round table materials showed how great the authority of the Dutch scientist and his influence on the Russian middle Ages [7].

\section{RESULTS}

In the concept of medieval culture, J. Heisinga develops the concept of «mythologeme», where myth is understood as a way of spiritual reorientation of man and society, which consists in the existence of an «ideal spiritual space», that reflects «the infinity of time and the fate of mankind» [2]. Speaking with sharp criticism of banal «progressivism» and rationalistic approach in considering the development and change of cultural and historical epochs, he reveals the deep connection between the phenomenon of culture, religion and art. Thus, J. Heisinga proves that not relativism and fatalism become the basis of religious consciousness, but the phenomenal significance of the idea of searching for the truth and meaning of life, which covers all spheres of the spiritual life of humanity in the statement of «The greatness of the human spirit and its salvation»[2]. Therefore, the basis of the concept of J. Heisinga «The idea of considering the middle ages as a self-valuable culture of «Joy, love», «Juicy maturity» of a full-fledged human life with its own forms of life and thinking, which in many ways prepared the Renaissance of Northern Europe [5]. The contrast of life (riches and poverty, suffering and ecstasy of love, epidemics and the light of hope) was presented (according to J. Heisinga the middle ages, the forms of «developed ritual», thanks to which the life of medieval society (including Church canons) reached the splendor of the mystery: 
1. the bell, as a symbol of the materiality of collective life ( the bells of Notre-Dame de Paris, the Cathedral of Milan in Antwerp);

2. processions-forms of civil urban life, medieval carnivals, public mourning (funerals of nobles and kings);

3. preaching-forms of the sacred and public in life (Brother Richard, Vincent Ferrer, etc.);

4. legends and images of the sermon - «Cross pain», «Terrible Court»; religious war (between the crusaders and Muslims VIII-X the Christians and Moors of XII$\mathrm{XV}$ centuries);

5. the cruelty of the Inquisition and greed of the crowd (the story of the citizens of Mons, the execution of Joan of Arc, the Inquisition and the like).

Many of the marked features of the «mystery» of medieval life, noted by J. Heisinga, are essentially universal. So, Potekhina I. in the article «From the history of Russian mediaevalism», emphasizes the features of the Orthodox Liturgy of medieval Russia, in which the canons of «conciliarity», bell ringing, prayer and other generally significant phenomena of the Christian Liturgy were formed [8].

The social life of this time («all the tender joy and clarity of the soul») - behind the author's thought, formed the desire for a beautiful life, which was reflected in the painting, in the transparent purity of the sublime music of Gregorian singing, the elegant and etiquette of medieval courtly poetry, the folk simplicity of minstrel songs. Aesthetic attitude to various forms of life (spiritual, secular, everyday urban and rural) has become an integral feature of the time, the attitude to life rises «to the level of style» (a strict hierarchy of fabrics, furs, clothing colors, the shape of hats). In «The Art Renewal Center. Online museum» presents numerous exhibits of attributes of medieval life, preserved and issued in different styles of subsequent epochs (Renaissance, Baroque, modern) [9]. People liked everything that was related to the sphere of aesthetics and took beautiful forms. In the Middle ages, a unique socio-spiritual Institute «minion» (the cult of chivalrous friendship) was formed. The more beauty and morality there was in the relations of life, the more the forms in which it was expressed were capable of becoming «Pure art». But the most striking thing in the aesthetic sense was the flourishing of three principles: valor, honor and love, the expression of which was the art of chivalry (chivalrous ideal, chivalrous poetry and music).

Musical and poetic forms became the basis of jousting tournaments about nobility, about love and passion, the vow of loyalty (Philippe de Maiziere, Louis of Orleans, Juan Manuel, Olivier de La Marche, Thomas Bazin). The stylization of love in the melodies of the Provencal troubadours, starting from the XII century, sounded in full force. Love became a field where all sorts of aesthetic and moral relationships could be nurtured. As noted by K. Kvashnin at research «Music performing intonation in the middle ages»: «The style of «Dolce» in its various national manifestations (Dante Alighieri, Christina of Pisa, Francesco Landino, Guillaume de Lorris , Jean Clopinel, Mina, Philippe de Vitry, Walter Menon, Charles Chatelain, Charles de Rochefort, Eustache Deschamps, etc.) became the expression of idyllic forms of musical and poetic art, forming the aesthetics, culture and art of «Ars novo» [10].

No less original views J. Heisinga on the problem of evaluating the Church art of the middle ages, including music.The leading concept for the author is «Figurative transformation of Faith», borrowed by the author from the treatise «Discourse on world history» by Jacob Bughart (XV century), which reveals the idea of the possible manifestation of the human spirit in religious forms of life. Following his reasoning, the ideas of transcendence, religious piety, sermons, images of Christ, the virgin Mary, the apostles and the prophets are generated by man himself, his spiritual experience, imprinted in religion, culture and art. At the same time, it emphasizes the close relationship between religious and secular spheres of life, as well as the use of secular and folk songs. In the «Liturgical drama». Thus, in the Liturgy «the action of Daniel» or «The way of gifts», the last Song about the coming of the Magi sounds in the spirit of folk songs, and secular motifs are used in Church forms (Guillaume Dufay-mass on the theme of secular songs «White Face «Like laughter»). As a consequence of this process, Huizinga, relying on medieval Chronicles, gives examples from the sermon of the Bishop of Salona, where John the Fearless is compared to the lamb). Our lady and Mary of Burgundy with Virgin.

Thanks to J. Huizinga art of Jean Fouquet and his virgin Mary (Right-hand side of the Melun diptych. about. 1450. The Royal Museum of fine arts, Antwerp), which, according to legend, depicts Agnes de Sorel-the king's mistress, for whom the Chevalier did not hide his passion, became a textbook example of the breadth of manners of medieval society. According to the researcher, the motet became the highest artistic form that reflects the mixing of religious and secular principles. Its cultural and social functioning depended on the content of the text crucified in it.

An original view of the relationship between religion and art in the middle ages gave modern researchers the opportunity to look at and evaluate the work of many artists of that time. Such studies include the work «Lucas van Leyden, J. Huizinga, And the Space of Play» by Apresyan R., which examines the work of the Dutch painter Lucas van Leyden (the greatest predecessor of Rembrandt) in the context of «Creative play». The author manages to create not only the image of the artist, but also to reveal his creative process through «...The type and character of his characters: society ladies and commoners, aristocrats and bourgeois, bright street scenes and half-tones of the inner world, hidden from prying eyes» $[11]$. 
No less striking sign of the influence of the cultural concept of Raising on modern researchers should be considered the prevailing views and assessments of the motet genre $[1,6,10]$. It was in the motet that the features of religious and secular culture were combined, expressed in the special intonation expressiveness of melos. Motets with verses of spiritual themes were performed both in Church and in secular settings (for example, in aristocratic courts); motets with texts of secular themes. Unlike other genres that were practiced in Western Europe in the Middle ages, the motet is a genre for demonstrating the professional skill of its Creator. As early as the thirteenth century, John de Groqueio wrote about the motet: «This type of music should not represent the presence of ordinary people who are not able to appreciate its refinement and carelessly listen to it. The motet is performed for educated people and generally for those who seek refinement in art» [1]. Despite the professional complexity of writing, it was the motet that became the conductor of the «verbal sharpness» of the poetic text, even allowing blasphemous phrases and epithets.

\section{CONCLUSION}

The study of the ways of development of the musical culture of the middle ages, its significance and place in the formation of humanism, spiritual, moral and aesthetic values of the culture of subsequent epochs from the standpoint of the cultural concept of Music. Heisinga is steadily gaining strength and makes it possible to significantly change the position of evaluating many phenomena of musical culture and art of the middle ages in the leading professional courses of modern music education, first of all «History of art», «History of art and musical styles», «History of musical culture», «History of foreign music». At the same time, the inclusion of a huge number of musical works by various authors of the middle ages in the process of teaching students gives the teacher the opportunity to significantly expand the analytical material on the theoretical subjects of «Polyphony», «Analysis of musical forms», «History of art», and «History of musical and artistic styles». Views of J. Huizinga undoubtedly influenced the formation of the cultural concept of the middle ages in modern science, and at present we are only on the threshold of understanding this phenomenon. A remarkable, in many ways unique study «Autumn of the middle Ages» can be included in the aspect of considering courses that train professional musicians of various directions.

\section{REFERENCES}

[1] O.I. Zhuravleva, Philosophical and cultural concept of J. Huizinga in the context of modern medieval studies, Theoretical and practical issues of cultural studies 2 (2008) 164-170.

[2] J. Huizinga, About the historical ideals of life, Overseas Publications Interchange Ltd, 1992.

[3] J. Huizinga, Duch civilisation in the seventeenth century and other essays, Co Ltd. London and Glasgow, Collins, 2012.

[4] J. Huizinga, Homo Ludens. Essay. A Thinking Man. Ideas that can change the world, ABC-Atticus, Hummingbird, 2019.

[5] J. Huizinga, Autumn Of The Middle Ages, ABCAtticus, Hummingbird, 2019.

[6] A. Lesovichenko, Knight medieval studies music, Workers of the musical field, Novosibirsk state regional scientific library, 2018.

[7] Unofficial medieval studies and the Soviet «cultural turn», Available at: /https://www.hse.ru/mirror/ pubs/share/142394418/.

[8] I. Potekhina, From the history of Russian medievalism, St. Petersburg medieval studies, Portal «Biografika» of Saint Petersburg state university and new opportunities in studying-Saint Petersburg, 2018.

[9] The Art Renewal Center, Online museum, Available at:

http://www.worldheritage.org/articles/Art_Renewal_C enter.

[10] K. Kvashnin, Music performing intonation in the middle ages, Bulletin of Tomsk state University. Cultural studies and art criticism 30 (2018) 121-130.

[11] R. Apressyan, Lukas van Leyden, J. Huizinga, And the Space of Play, Ethical Thought 18(2) (2018) 116-128. 